\title{
Analysis on the Ways of Constructing Excellent Course of Financial Management Specialty
}

\author{
Ming Zhao ${ }^{1}$ and En Deng ${ }^{2^{*}}$
}

Hunan Radio and Television University, Changsha 410004

37908338@qq.com

*The corresponding author

\begin{abstract}
Under the background of the Internet, higher vocational education makes full use of Internet technology to build professional network quality course. Improving the teaching ability of professional teachers, meeting the students' individualized autonomous learning, realizing the full sharing of high quality teaching resources and improving the information teaching level of vocational colleges are the important contents of the current teaching reform of higher vocational colleges. This paper discusses from the aspects of the teaching staff, network platform, teaching content and network simulation practice base in the construction of fine course of financial management specialty network in vocational colleges, and gives the corresponding countermeasures of network quality course construction.
\end{abstract}

Keyword: Vocational College; MSc financial management; Network; Network quality course

\section{浅析金融管理专业网络精品课程建设途径}

\author{
赵明 ${ }^{1}$, 邓恩 ${ }^{2 *}$ \\ 湖南广播电视大学, 湖南长沙 410004
}

摘要: 互联网背景下, 高等职业教育充分利用互联网技术建设专业的网络精品课程, 提升专业教师网络教学能力、满足 学生个性化自主学习、实现专业课程优质教学资源完全共享、提高职业院校信息化教学水平是当前高职院校教育教学改革的 重要内容。从高职院校金融管理专业网络精品课程建设中的师资队伍、网络平台、教学内容、网络仿真实习基地等方面进行 探讨, 并给出网络精品课程建设的相应对策。

关键词: 高职院校; 金融管理专业; 网络; 精品课程

中图分类号: G40-011 文献标志码: A

\section{引言}

随着互联网技术的飞速发展, 为了与社会发展相适应, 我国高等职业教育就需要打破传统的教育教学 方式把金融管理专业的精品课程建设与互联网结合起来，让每一位专业课程教师利用互联网技术来建设高 职院校的网络精品课程, 利用网络来展现精品课程的教学内容及实施教学活动, 用此种形式来打破高职院 校教学工作的时间和空间限制, 用灵活的方式来满足学生个性化自主学习, 既提高高职院校的信息化教学 水平, 又提升了专业教师的网络教学能力, 还实现了金融管理专业课程的优质教学资源完全共享。

\section{1.金融管理专业网络精品课程建设的现实意义}

\section{1 金融管理专业网络精品课程建设对专业学生学习}

高职院校金融管理专业采用网络教学模式, 通过网络将专业的精品课程展现给学生。有利于学生的专 业课程学习不受时间和空间限制; 有利于学生体验到先进的教学方式; 有助于灵活的满足学生个性化自主 学习需求, 有助于激发学生的学习积极性。

\section{2 金融管理专业网络精品课程建设对专业课程教师教学}


高职院校金融管理专业将精品课程通过网络教学, 有助于高职院校组建双师型教学团队; 有利于提升 高职院校专业课程教师的网络教学能力; 有助于合理的将高职院校金融管理专业教师的精品课程教学方案 优质化; 有利于高职院校专业课程教师及时更新网络精品课程内容。

\section{3 金融管理专业网络精品课程建设对高职院校专业课程建设}

高职院校金融管理专业通过网络精品课程建设，有助于高职院校对金融管理专业建设、课程体系建设 及教学改革; 有利于促进金融管理专业网络精品课程的开发与完善; 有利于高职院校实现专业精品课程教 学资源完全共享; 有利于提升高职院校金融管理专业教育办学成效; 也为高职院校培养金融方面的高技能 应用型人才提供新的条件和开辟新的途径。

\section{2.金融管理专业网络精品课程建设的现状及问题}

\section{1 高职院校网络精品课程建设实际情况}

目前, 我国高职高专网络精品课程已达到 5924 门, 资源库分为 409630 类。但从高职院校网络精品课 程建设的实际情况来看, 其建设的体制有点僵化, 特别是高职院校双师型教师比较缺乏, 精品课程网络化 建设不仅是“重申报，轻建设”，而且在网络精品课程制作的模块设计上也没有在线交互、答疑反馈等模块。 从高职院校网络精品课程目前现状来看, 一般都没有专门的网络课程教学服务平台, 网络精品课程教学资 源也没有完全共享, 更谈不上对网络精品课程内容及时更新与完善。

\section{2 高职院校金融管理专业网络精品课程建设实际情况}

高职院校金融管理专业在网络精品课程建设时，从学习情境来设计教学活动的往往很少，而且其专业 课程与行业或企业岗位需要衔接也是不到位, 体现在金融管理专业课程体系中实践课程少, 乃至给实操安 排的时间更少; 其内涵与就业也就有着很大的不同，导致金融管理专业网络精品课程建设与高等职业教育 人才培养目标存在一定的差距。

\section{3 高职院校金融管理专业网络精品课程建设后使用情况}

在高职院校金融管理专业网络精品课程建设后，从其评价方式与反馈形式来看，它也比较单一，往往 只有网路精品课程的作业和考试, 很少考虑到学生对网络精品课程的智能评价, 而且在反馈方面基本上没 有考虑到网络精品课程的学前测试模块和答疑反馈模块; 不利于金融管理专业网络精品课程的建设，也不 利于网络精品课程内容及时更新与完善。

\section{3.金融管理专业网络精品课程的建设途径}

\section{1 注重与企业深度融合，培养双师型教师队伍}

为了实现高等职业教育金融管理专业以职业岗位群的职责、任务、能力要求来培养人才目的，需要高 职院校金融管理专业与企业深度合作。以湖南网络工程职业学院金融管理专业为例，专业与光大证券有限 责任公司和世纪证券有限责任公司及中国人寿保险公司开展合作为该专业学生提供客户服务与营销服务 实训岗位、与红塔证券有限责任公司开展合作让该专业毕业生能到公司进行定岗实习、与湖南招商银行和 湖南建设银行开展合作让专业学生到银行进行企业认知实习; 专业与百度百捷公司签订合作协议开展深度 合作，按照金融相关工作岗位要求结合高等职业教育人才培养模式，由企业与学校共同进行授课、企业负 责安排学生顶岗实习、毕业后企业根据学生具体能力安排到金融相关的岗位上工作。

高职院校金融管理专业通过将校内专业教师选派到金融相关的行业或企业工作岗位进行工作、培训， 
促进高职院校双师型教师队伍建设, 为金融管理专业网络精品课程建设提供一支结构合理、人员稳定、教 学水平高、教学效果好的教师团队。在双师型教师团队建设中, 注重引进或者培养高职称与高学历的教师, 做到师资力量合理且优化, 正真的为高职院校的网络精品课程建设和学生教育教学服务提供强大的师资力 量。以湖南网络工程职业学院金融管理专业为例, 该专业课程校内师资队伍有 12 人, 其中 4 位教授, 3 位 副教授, 副高及以上占教师队伍的 $58 \%$; 讲师 4 人占教学队伍的 $33 \%$ 。每一位教师都管理一门或者几门专 业课程, 能独立承担专业课程的建设与授课, 并且还有 1 位教师专门辅助教学和实验指导。同时专业还聘 请校外企业专家或高管来参与专业课程体系建设和授课。如：聘请湖南招商银行和湖南建设银行电力支行 行长、红塔证券责任有限公司总经理、世纪证券有限责任公司证券分析师担任该专业指导委员会委员共同 确定专业培养目标和发展方向, 根据行业岗位需求修订专业课程标准, 督导教学质量, 协调组织实施学生 的实训和就业工作，合作企业还选派“企业师傅”到学校为专业的学生讲授专业相关的工作岗位实训和实践 内容。

\section{2 加强教学网站和多媒体网络教学平台建设}

为了适应社会发展, 将高等职业教育与互联网紧密结合。从现实情况看, 高职院校需要为学生提供一 个自主学习的学习环境, 以金融管理专业为例, 专业就需建设一个专业课程的教学网站和网络课程学习平 台, 根据行业与企业需求用网络展现专业的精品课程。在确定金融管理专业课程时, 先调查行业与企业所 需人员应具备的基本技能, 再来设计专业的基础课程和核心课程, 在此基础上按照高等职业教育的精品课 程建设标准，在校内外专家的指导下建设金融管理专业的精品课程，并不断扩充专业的精品课程的学习资 源, 如: 专业课程的教学大纲、教学计划、集中实训任务书、电子教案、教学录像、教学教材、实验指导、 复习指导课件、课程案例和习题库等等。还应注重专业模拟实训室和多媒体教室建设, 充分发挥专业课程 的教学资源的学习功能, 在此基础上建立以学生用户为中心的交互式的与教学需求相近的网络教学平台, 并给学生一个详细的使用指南, 要能通过精品课程网络交流平台实现金融管理专业的课程教学资源完全共 享。

以湖南网络工程职业学院为例, 合理利用湖南广播电视大学网络优势, 建立网络仿真虚拟项目。如: 金融管理专业虚拟班级及虚拟课堂, 为学生线上线下学习和专业课程资源交流提供现代化网络学习平台, 给金融管理专业的学生和课程老师分别配给权限, 仿电大 BBS 论坛模式通过网络与学生进行网上讨论和答 疑, 仿世界大学生城空间按照专业网络课程上传教学视频资源及给学生布置作业、批改作业、在线测试, 这样让金融管理专业的课程教学活动打破时间和空间限制, 通过线上线下的学习模式获得很好的学习效 果。

\section{3 重视专业课程教学内容、教学资源建设及教学活动组织与实施}

高职院校要根据高等职业教育精品课程建设标准，按照学校对专业的整体规划设定专业精品课程建设 的思路和目标，在此基础上对金融管理专业的课程体系进行修订并完善。结合行业与企业的职业工作岗位 (如: 银行柜员、大堂经理、客户经理、会计岗位) 来设计教学目标, 构建知识内容, 在此基础上开设金 融管理专业课程, 依据岗位技能要求来设定课堂教学内容, 设计以学生为中心, 选择恰当媒体采用多种传 播方式, 运用互联网技术, 通过网络实施教学与管理, 充分交流专业精品课程的教学资源 (如: 导学、自 学、互学、助学及督学等资源, 其中互学资源主要是主题讨论、自由讨论、交流园地、学习讨论区、互动 
平台、博客群、微博互动资料; 督学资源基本上是在线测试、在线作业并给出测试结果), 合理的利用金 融管理软件技术, 通过插入与专业相关的图表、图片、动画、音频、视频等多媒体信息, 实现多变且生动 效果，从而达到利用网络技术实现课程优质教学资源完全共享和教学资源可持续建设。

从网络精品课程的校内评审情况来看, 它是利用网络技术将教学活动组织与实施, 通过学习活动形式、 教学评价、教学反馈 (对教学内容配有教学视频讲解) 和教学过程记录 (记录学生学习知识与资料查找的 情况, 与老师之间、学生之间互动交流情况) 实施。高职院校通过网络改革金融管理专业实践教学的形式 与内容, 采用灵活多样的考核形式, 通过灵活的评分标准来培养学生的创新能力。高职院校要建立健全专 业精品课程评价体系、学生评教制度, 促进网络精品课程的不断完善与发展, 为金融管理专业网络精品课 程在高职院校广泛建设并推广使用奠定坚实的基础。

\section{4 注重实践和产学研合作, 建立专业网络仿真实习基地}

职业教育是以培养技能型人才为目标, 这就要求高等职业教育在教学中注重学生的专业实践能力培 养。为了达到这个要求, 金融管理专业就需注重产学研相结合, 与金融相关的行业、企业合作, 组织专业 的学生在企业从事金融相关的工作岗位上实习, 构建高职院校的工学结合的长效机制; 加强金融管理专业 的实践教学软件及硬件设施建设, 组织课程的专业教师培训, 甚至开展网络技术学习, 提升其网络教学工 作能力。

积极寻求与企业合作, 大力建设金融管理专业网络实训项目的实习基地。以湖南网络工程职业学院金 融管理专业为例, 首先, 完善银行业务综合岗位仿真实训、银行理财产品业务和保险业务洽谈仿真实训、 证券交易模拟实训室、典阅银行业务模拟软件、杭锐电脑传票输入训练系统 2009 版、股票模拟训练软件、 用友财务软件等实训功能, 合理使用学院智慧商务跨专业仿真实训中心为金融管理专业学生们授课, 提高 金融管理专业综合实训软件使用效率; 其次, 建立金融业务沙盘模拟和模拟炒股实训中心，努力拓展高职 院校的校内实训平台; 最后, 加强与金融相关行业和企业合作, 努力构建高职院校校外实习基地, 依托证 券公司、保险公司、中小银行等业务办理情况, 来建设专业网络仿真实习基地让学生跟着做, 从而提高学 生柜台操作、理财产品销售、客户服务等岗位的实际技能。

\section{4.结论}

总之, 高职院校的金融管理专业网络精品课程建设是一个长期的、可持续发展的过程。为了保障金融 管理专业网络精品课程建设还需高职院校建立与之相应的激励机制, 鼓励所有专业教师都积极主动的承担 网络精品课程建设, 学校评审通过后给与网络精品课程建设项目核拨款项, 建好后还给与相应的奖励, 鼓 励高水平的专业教师积极投身学校的教育教学工作来, 与此同时, 高职院校还要注重金融管理专业课程网 页建设、网络精品课程学习平台建设。高职院校要通过金融管理专业网络精品课程的建设, 建立健全网络 精品课程的合理评价体系, 促使网络精品课程建设不断完善和发展, 通过精品课程网络平台, 为金融管理 专业的课程教师和学生学习提供双向服务, 提升高职教育的教育教学质量, 满足高职院校培养金融方面人 才需要。

\section{致谢}

本文系湖南广播电视大学科研项目一般课题 (XDK2016-C-17) 和 (XDK2016-C-6)、湖南省教育厅科 学研究项目课题（13C129）、湖南省教育科学 “十三五” 规划课题（XJK016CZY021）的阶段性研究成果。 


\section{Acknowledgement}

The paper is the stage research result of Hunan Provincial Radio and Television University Scientific Research Project General Subject (XDK2016-C-17) and (XDK2016-C-6), Hunan Provincial Education Department Science Research Project (13C129), Hunan Province Education Science "Thirteen-five" Planning Project (XDK2016-C-6), (XDK2016-C- XJK016CZY021) .

\section{参考文献:}

[1] 赵明.浅析开放式高职网络精品课程建设——金融专业为例[J],知识文库,2017 年 2 月第 6 期 51-52 页

[2] 袁丽、邱桂花.网络精品课程建设的思考[J],时代农机，2015 年第 4 期 66-67 页

[3] 韩光明、鲍炜显.高校网络精品课程建设之我见[J].文教资料，2014 年第 22 期总第 654 期[12]141-143页

[4] 赵静.我国网络精品课程建设现状分析与反思——以《教育技术学》课程为例[J],中国医学教育技术, 2014 年 4 月第 28 卷第 2 期 150-152 页

[5] 刘波.会计专业网络精品课程建设的实践与思考 [J], 武汉商业服务学院学报 2012 年 2 月第 26 卷第 1 期 71-73 页

[6] 孙娜.计算机网络精品课程建设[J],吉林广播电视大学学报, 2010 年第 6 期 (总第 102 期) 74-75 页

[7] 石娜、石梅香.高职网络精品课程资源运行情况的调查与分析一以天津职业大学为例 [J].职业教育研究, 2010 年 8 月 第 21 期 38-39 页

[8] 湖南网络工程职业学院 2015 级人才培养方案汇编, 2016 年 6 月第 1 卷 326-337 页

作者简介: 赵明 (1979--) 男, 湖南广播电视大学经济学讲师, 研究方向: 高职教育、金融学及其教学研究; 通信作者: 邓恩 (1978--), 男, 湖南大学在读博士、湖南广播电视大学经济学副教授, 研究方向: 高职教育、金融学及其教学研究。

\section{Reference:}

[1] Zhao Ming. Analysis on the Construction of Open-ended Excellent Course in Vocational Colleges - Taking Finance Major as an Example. [J], Knowledge Base, February 2017, Issue 6, pp. 51-52

[2] Yuan Li, Qiu Guihua. Reflections on the Construction of Network Quality Course. [J], Time Agricultural Machinery, No. 4, 2015, pp. 66-67

[3] Han Guangming, Bao Weiyu. My Opinion on the Construction of Network Quality Course in Colleges and Universities. [J]. Cultural and Educational Materials, 2014, No. 22, Total 654 [12] 141-143 Page

[4] Zhao Jing. Analysis and Reflection on the Current Situation of Network Quality Course Construction in China - Taking "Education Technology" Course as an Example. [J], Chinese Medical Education Technology, April 2014 Volume 28, No. 2, pp. 150-152

[5] Liu Bo. Practice and Thought on the Quality Course Construction of Accounting Professional Network. [J], Journal of Wuhan Institute of Business Services, February 2012, Vol. 26, No. 1, pp. 71-73

[6] Sun Na. Construction of Computer Network Quality Course [J] Journal of Jilin Radio \& TV University, No.6, 2010 (total 102) 74-75

[7] Shi Na, Shi Meixiang. Investigation and Analysis on the Operation of Quality Course Resources in Higher Vocational Colleges - Taking Tianjin Vocational University as an Example[J] Vocational Education Research, August 2010, Issue 21, pp. 38-39

[8] Directory of Personnel Training Program Compilation of 2015 Grade in Hunan Network Engineering Vocational College. June 2016, Vol. 1, pp. 326-337 